\title{
Wearing shades in the bright future of digital media: Limitations of narratives of media power in Egyptian resistance
}

\section{Karin Gwinn Wilkins}

MedieKultur 2012, 52, 49-61

Published by SMID | Society of Media researchers In Denmark | www.smid.dk The online version of this text can be found open access at www.mediekultur.dk

Political engagement means more than reliance on a single medium, but requires collective human action. In making this argument, I consider how the media landscape, along with social and political contexts, have contributed to this process of shifting political power in Egypt. This background contextualizes the limitations of a dominant Hollywood narrative in U.S. media, not only telling a reductive tale of hero, victim and villain, but also privileging the role of social media as an anthropomorphic heroic sidekick. Mediated communication can be valuable as a vehicle for mobilization and as a site for political contestation, but it is the access to the production and reception of knowledge that matters. In essence, the critical issue in political resistance is power, not technology.

\section{Introduction}

Political engagement means more than one man leaving office, more than voting, more than a pithy slogan, such as "Facebook revolution." To assume the power of media, particularly "new" digital technologies, as central heroes in political resistance is to miss the human context of communication. To engage resistance and succeed in meaningful change against longstanding political corruption requires steadfast courage, collective work, and long-term dedication. To reduce the significant and still on-going political resistance in Egypt to a 
"Facebook" or "Twitter revolution," as has been done in much of the Western English-language press, is not only misleading, but it is also disrespectful (Alterman, 2011). In making this argument, I consider how the media landscape, along with social and political contexts, have contributed to this process of shifting political power in Egypt as of 2011. This background contextualizes the limitations of a dominant Hollywood narrative prevalent in U.S. media discourse on this resistance.

The theoretical framework guiding this work engages a critical realist approach to political communication research (Deacon, Pickering, Golding, \& Murdock, 1999), recognizing human agency as both creating and being limited by social structures. Instead of assuming a pluralist network of power, in which all citizens have equal access to resources and ability to engage them, I begin with the assumption that some groups have more control over resources than others, and work through hegemonic processes to maintain their domination. Attempts to manipulate ideologies can be seen as working to justify inequitable distributions of material goods and control over key decisions. Seeing this hegemony as a dynamic process of contestation through communication, political resistance offers potential for hope in corrupt political systems, yet also needs to be understood within a broader context of national, regional, and global agencies constraining that potential given their own interests (Downing, 1996).

Historical political protests in Egypt, which can be usefully described from previous decades as well as centuries or even millennia, illustrate this key point well. Political power has been captured and challenged by pharaohs, kings, presidents, armies, political movements, and more. Encompassing a complex society integrating many varied allegiances to Islam with Coptic Christians and secular citizens, as well as socio-economic and generational divisions that divide access to media and other resources, Egyptian political history illustrates how hegemonic domination can be challenged.

Key to this argument is that narratives are positioned within power structures, and that in order to be aware of the broader contexts of these perspectives we need a reflexivity (Krippendorff, 2008) that allows us to move not just from detached observer to participants, but toward a grounded awareness of that participatory process. Our narratives, just as our theories, guide what we "know": psychiatrists tend to guide diverse issues clients raise into the diagnoses of their specialties; women socialized through stories of female inferiority become comfortable in subservient positions; and development organizations focus on social problems they are institutionally equipped to resolve. Whether as organizations, professionals, or social beings, we act and think in accordance with the structured stories that constitute our conventional wisdom. Yet stories themselves change over time, and serve as sites for political contest; thus there is potential for shifts in narratives through reflexivity and political engagement. 


\section{Media landscape}

The media landscape in the region within and approximate to the Middle East integrates a wide variety of communication technologies, recently known for branded digital media such as Facebook, but actually engaging so much more. Transnational satellite television in particular stands out as one of the most critical features of this mediated environment (Alterman, 2011). However, to reduce a complex media environment to a single technology obscures the central issue of power, when what matters is who has access to the production and reception of mediated content.

The Arab region has been marked by significant trends establishing an increasing number of sites for media production and distribution. The regional television industry in particular has changed, from previously nationally focused stations to transnational systems, more likely to partner private funding with public sponsorship than before (Sakr, 2007). The number of transnational stations has proliferated dramatically, including those interested in news as a profitable industry, such as Al Arabiya, attracting local journalists away from smaller stations with much higher compensation offers, as well as those with obvious political agendas, such as Al Hurra, administered through U.S. government agencies. By 2011, audiences in the Middle East region had access to more than 500 independent transnational satellite television channels (Wright, 2011, p. 26). These channels include a variety of programming, not only news and drama, but also those devoted to religion, having increased from one to about 80 in the last ten years (Wright, 2011, p. 185).

In her description of theoretical models, Sakr (2007) recognizes that a market orientation is less prevalent among the television industries in this region, particularly given the lack of reliable data required for securing global advertising business (Kraidy, 2010). While the potential to reach a large market might be appealing for the industry if attempting to follow a private business approach, government regulation along with cultural and linguistic differences have served as considerable constraints. The extent to which a broadcasting station can capitalize on Arabic as a shared language depends upon the abilities of people with quite different dialects to comprehend the people onscreen. Television genres that use less complex dialogue, such as reality television, drama, and music, have a wider transnational appeal than news and information programming (Kraidy, 2010).

Yet Al Jazeera, now broadcasting in English as well as Arabic, has emerged as a prominent channel of news in the region, even among the many competitors having emerged since 2003. Before that time, this station, funded by Qatari Emir Sheikh Hamad Al-Thani, dominated the region in its articulation of a pan-Arab programming approach (El-Nawawy \& Iskander, 2003). Al Jazeera became known for its provocative talk shows (Lynch, 2006) and political critiques of the U.S. and Arab governments, other than Qatar (El-Nawawy \& Iskander, 2003). In response, the U.S. government was highly critical of this station (although this changed later, and increasingly U.S. officials are interviewed and appear as guests on this channel), as was Bahrain (expelling a talk show host), Libya (recalling their ambassador to Qatar), Saudi Arabia (requesting Saudi advertising agencies not to sponsor programming), 
the Palestinian Authority (closing offices), while others such as Egypt reacted with ambivalence (El-Nawawy \& Iskander, 2003). Part of this station's integrity was seen as due to the lack of government control and its reliance on independent financing. Since 2002, other transnational stations have offered regional news, some such as the Saudi funded MBC with more moderate positions on Palestinian issues (Lynch, 2006). Although Al Jazeera no longer ruled the Arab media as a central provider, its entry into the industry marked critical shifts in the presentation of controversial issues and in integrating interactive formats. Kraidy (2010) argues that it is not just Al Jazeera though that takes on controversial issues, but reality television also engages sensitive areas, such as gender relations, political participation, and the role of Islam in public life.

This interactive feature of $A /$ Jazeera's talk show formats contributed to its appeal (Lynch, 2006), much as the integration of audience interaction in reality television shows on transnational stations did (Kraidy, 2010). In addition to creating space for audience reaction to contestants, competitive talent shows allowed audiences to text in their votes, enabling a commodified form of participation in the outcome. Lynch (2006) and Kraidy (2010) raise similar points in their affirmation of this interactive potential as not only increasing the popularity of these programs, but even more importantly as moving private debate into a more publicly open and contentious space. While neither author claims that these programs ultimately created an "Arab public sphere" (Lynch, 2006), the substance and format of these television programs contributed to a climate in which open public critique was considered more acceptable.

Kraidy (2010) rightly reminds us though that it is not just television, or even just social media, that dictate social life, but instead that these media need to be understood as a more complex set of technologies and networks constituting a "hypermedia space." This convergent, saturated, interactive media space enables people to participate and express themselves on political and other matters. This contested, complex mediated space contributes to a more broadly conceived new Arab public sphere as described by Lynch, and phrased by others as a comprehensive "al Jazeera effect" (Sieb's (2008) articulation of this recognizes the importance of the station, but uses the phrase to reference the broader media environment).

This complex media space, encompassing much more than one station or a singular medium, contributes to a climate of participatory engagement, albeit with considerable constraints. Access to the means of television production is still limited to those with wealth, though reception has become increasingly available to a variety of constituents; access to the means to create digital content may be a valuable asset for those who are connected, but this network connectivity remains exclusive to those with literacy, expertise, and resources. Government regulation and opposition also constrain peoples' access to the production and distribution of information, as well as the boundaries dictating content and interactivity. Policies limiting content range from those prohibiting political critique 
to those concerned with women's representation, either concerned with their problematic objectification or their very presence (Kraidy, 2010).

Given these political and economic constraints, this hyper-mediated space still has great cultural and political potential. Transnational satellite television has done well in fostering a regional pan-Arab identity, all the more resonant when news coverage "zooms out" depicting the magnitude of political mobilization. Wide-angle visual coverage permits groups with popular appeal to counter political authorities wishing to minimize their importance (Kraidy, 2010).

While the potential for the interactive features of reality television and news programming to engage viewers in active responses does offer meaningful engagement, this form of participation is necessarily limited to a prescribed script and format. Audiences may vote through texts for their favourite contestant on a reality show, or counter interviewed subjects on a talk show, but these votes and responses fit within a structure of previously determined casts of characters and perspectives. Rather than approaching a more serious level of power in which participants have the ability to change the rules of the game, their control is tightly structured. Audiences are just that - audiences. Even given Sakr's (2007) television model addressing audiences as citizens, these are still constructed groups operating as a target for political intervention, rather than an actively engaged group determining the processes and direction of communicative content. Still, satellite television offers a widely more accessible mediated channel than that of the Internet (Sieb, 2008; Alterman, 2011).

While television appeals to a wider set of constituencies given its visual appeal and cost, rising literacy rates, increasing bandwidth, and cheaper computers and telephones make Internet services a growing vehicle for information transmission as well as collaborative content creation. An Internet platform for dialogue attracts those hoping to avoid governmental control, which is more easily accorded to television and radio broadcasting. More easily avoiding state control, digital media provide a space for public dialogue critiquing the legitimacy of official policies (Lynch, 2006).

In his discussion of a "new Arab public," Lynch (2006) describes this sphere, emerging since the 1990s, as articulating "active arguments before an audience about issues of shared concern, " enabled through "the rise of new information and communication technologies" (pp. 32-33). Even earlier, Eickelman and Anderson (2003) considered the emergence of a "new" public created through digital media, allowing debate over the ideologies and practices of Islam. The contributors to their edited volume confirm with several cases the editors' argument that new digital media allowed a decentralized challenge to Muslim authority, by offering potentially anonymous, flexible platforms for more participants that blurred private and public distinctions.

In sum, transnational satellite television offers a prominent and accessible source of information. Al Jazeera has been recognized for covering the Egyptian protests with a sympathetic, human angle as a "revolution," enumerating those killed and injured, and capitalizing on the telegenic appeal of Tahrir square as a setting, just as it had on others who became 
iconic figures, i.e., Mohamad Bouazizi in Tunisia and Neda Agha-Soltan in Iran. Digital media also contributed to the dissemination of these iconic images of martyrs and movements, offering a decentralized perspective at times sharply divergent from news generated through Egyptian state television and radio stations. Moreover, digital media allowed organizers to confer with others in Tunisia and elsewhere in their strategic planning, to mobilize those with access to the Internet, and to reach indirectly others through critical social networks and mobile phones. Even during the period in which the Egyptian government was able to shut down the Internet and cell phone service and to block some satellite television channels, people did find ways to communicate and to organize (Alterman, 2011), as have other protestors across the region.

The context of media access in Egypt needs to be recognized when considering the potential for technologies to contribute to human collective action. While most people have access to television (95 per cent have televisions and 70 per cent have satellite TV; Alterman, 2011) and many to cell phones (about 70 per cent), only 20 per cent use the Internet, with only about 6 per cent on Facebook (Wright, 2011). Given a national population of 85 million, this means approximately 5 million people were actively using Facebook. Many fewer (less than .001 per cent) were using twitter (Wilson \& Dunn, 2011). Tending toward the young, educated, and wealthy, this communicative tool did provide a key contributing, though not solitary, factor enabling the mobilization of protests. In contrast to much of the other state-owned and distrusted media sources, these social media offered a more trusted source of information for those with access (Iskander, 2011). For these elite, social media contributed to mobilization, and served as an archive of information for those outside of the territory of protests. However, the broader engagement of political resistance needs to be understood within the social and political context leading to frustration and potential for action.

\section{Social and political context}

Until 2011, political resistance in the Middle East seemed futile against powerful and corrupt regimes, and yet there is a historical context in which frustrations did inspire collective action. Well-organized and popular political resistance in Iran fell short of dramatic change in leadership, despite challenges to the legitimacy of the 2009 elections (Kamalipour, 2010). The Kefaya movement in Egypt, with roots in protesting U.S. invasion of Iraq in 2003, shifted in rhetoric to oppose Mubarak, but did not succeed in mobilizing large crowds for public demonstrations (Lynch, 2006). Yet, by 2010, labour strikes and other protests on varied issues, such as foreign policy and national economy, had increased dramatically in Egypt (Alterman, 2011; Iskander, 2011).

Although these efforts failed in their initial goals, they contributed toward creating a climate of resistance. These political movements coincided with several trends of resistance among youth through cultural vehicles, more within their control than state dominated 
media systems. Wright (2011) chronicles several means of cultural expression used to voice political opposition by youth in this region: promoting hip-hop music as political expression (p. 123); sponsoring human rights film festivals as awareness raising (pp. 140-141); creating comedy routines to counter prejudice; and resisting generational wardrobe choices, toward a more colourful "pink hejab" representation, cleverly ensuring authenticity while projecting power in a patriarchal system. Given that one-third of residents in the Arab region fall within the age range of 15-29 (Wright, 2011, p. 26), there is great potential for youth, increasingly frustrated with a lack of employment or direct political influence, to become a mobilized, active community in the process of political resistance. Khali (2011) situates Arab youth at the very centre of political activism in the region, performing street demonstrations facilitated through youth-generated media, noted for their creativity and energy, not following the logic of mainstream media dominated by corporate or government agendas. Through offering a means of controlling the production of images and words, youth media counter problematic stereotypes, offer more trusted information, and serve as catalysts for social change (Iskander, 2011; Khalil, 2011).

Egyptian youth are particularly unhappy, one out of four being unemployed, and about three out of four announcing in public polls prior to the January movement that they were deeply dissatisfied with their government (Alterman, 2011; Wright, 2011). Their frustration with the economy was widely shared across generations, with 10 per cent inflation and food prices doubling, meaning that the staple food of tomatoes was increasingly out of reach (Alterman, 2011); decades earlier, World Bank dictates requesting that the government raise the price of bread led to considerable popular protests. When the November 2010 elections resulted in an increased concentration of power, the fear of another Mubarak as the next leader of the country depressed citizens even further.

These frustrations had been taking shape in the form of political protests, with labour unions organizing toward strikes in 2010, along with the Kefiya movement initiated many years earlier (Alterman, 2011). Attracting a few hundred people at a time to protest issues such as Egyptian corruption and U.S. intervention in Iraq, this movement helped bridge secular liberal youth with Islamist and other communities.

Initial protests planned for January $25^{\text {th }}$, the national holiday meant to celebrate police in Egypt, were orchestrated through Wael Ghoneim, who organized a Facebook group in commemoration of the young man, Khalid Mohamed Said, killed in Alexandria by police when he was ready to upload evidence to the Internet of police corruption (Iskander, 2011). This particular group had a half-million followers (Alterman, 2011). Initial protests for social change shifted toward slogans focusing on Mubarak and economic frustration, leading three days later, on January $28^{\text {th }}$, to a "Day of Rage" (Wright, 2011). Iskander (2011) argues that social media will not remain relevant to national political dialogue in this context unless rooted in broader communication processes and civil society. Based on their interviews and surveys with protestors and coordinators, Wilson and Dunn (2011) concur, recognizing the importance of telephones, satellite television, and print as more relevant to protestors than 
Internet services such as Facebook (texting fell in between print and Facebook as a source reportedly used by protest participants).

As the crowds in Tahrir Square grew, the telegenic appeal of the story attracted a great deal of transnational satellite television coverage. Despite the government's interruption of mobile networks, Internet services, and some satellite television channels, people learned about events and strategies through a variety of communicative means. And even though not widely accessible, the Egyptian military posted its announcements on a Facebook page following Mubarak's resignation (Iskander, 2011). At the time of this writing, elections are in process, while questions of army dominance and future governance remain.

\section{US media narratives of Egyptian protest}

In their telling of this story, U.S. media rely on Orientalist narratives, not only essentializing complex communities to a reductive tale of hero, victim, and villain, but also privileging the role of social media as an anthropomorphic heroic sidekick, indispensable to the success of the movement. In this sense, the technological prowess of social media stands in for the U.S. itself as saviour.

While Hollywood conventions follow uplifting narratives in more general terms (Rameriz-Berg, 2010), focusing on action-adventure as a genre offers more specific terms toward the articulation of an Orientalist framework (Park \& Wilkins, 2005; Said, 1978). Film genres themselves serve as a set of familiar conventions, understood through the production and interpretation of film professionals and audiences. Action-adventure tropes are identified through the industry as a way of packaging games as well as film (McKee, 1997; Neale, 2004). As a game, action-adventure involves players' involvement in solving situational challenges encountered through the participants' avatars. As an approach to film, action-adventure circumscribes a narrative in which a lone masculine hero (though female heroes are gaining in visibility) vanquishes evil, personified through villains. In Hollywood versions, villains typically represent foreign (non-American) racial "others" (Marchetti, 1989), paving the way for a characterization of Muslim and Arab men more likely as villains than as victims or heroes (Dittmer, 2005; Shaheen, 2002; Wilkins \& Downing, 2002). This "Hollywood narrative" transcends genre, articulating characters and plot whether describing action-adventure film or news stories of Arab communities.

The heroes of this tale are the attractive and technologically savvy youth, resonant with a Western audience in terms of their appearance and projected exuberance, working to thwart the villainous older men who victimize women and children. Following the trajectory of the Hollywood narrative, authors of this mediated discourse would like to conclude the tale with visuals of crowds cheering as the nominal leader steps away from office. Emphasis on the contrived event of Saddam Hussein's statue being toppled in Iraq illustrates the symbolic import of this as a media event, meant to complete the tale, rather than recognizing that political transition requires much more than a change in leadership. 
Understanding mediated discourse as a particular perspective rooted in political-economic agendas is critical in our assessment of not only political resistance itself, but also of how we learn about that resistance in a global context. The Hollywood narrative is grounded in a Western Orientalist perspective, institutionalized through foreign aid, military intervention, and economic dominance. The persistence of Orientalism across U.S. approaches to foreign aid, as well as guiding principles in action-adventure and film, reinforce this perspective as conventional wisdom, with serious consequences to those consuming U.S. media, as well as those engaging in political resistance who require understanding and resources. Memories of action-adventure film become particularly poignant for those with little experience or knowledge of Arab culture, limiting knowledge of the region, contributing to prejudice, and enhancing the belief that these films portray a "realistic" vision of Arab communities; Arab American viewers, in contrast, find these stereotypes immensely offensive and difficult to negotiate in traveling through airports and living in the U.S. (Wilkins, 2008).

It is not the effects of a single text that are of concern though, but rather the accumulation of images dehumanizing and depoliticizing Arab culture. This narrative can be discerned in U.S. approaches to foreign aid as early as the writings of Daniel Lerner (1958), when he states: "What America is ... the modernizing Middle East seeks to become" (p. 79). Similar to the action-adventure narrative, we have a tale of a suffering victim (an amorphous group of people, more often than not depicted as "women and children"), whose cause is recognized as a white, male, American hero vanquishes an evil older Arab male. In the discourse of development, the villain personifies older traditions, while the American hero brings technologies to the suffering people, thus becoming their appreciated hero (Wilkins, 2004).

Other analyses of U.S. news coverage of Palestinian issues illustrate a remarkable similarity to the narrative of the film The Siege (Noakes \& Wilkins, 2002; Wilkins \& Downing, 2002). U.S. news was more sympathetic, consistently articulating the U.S. as the active hero and Israel as the victim, voice, and context; what did change over time was the portrayal of Palestinian actions, being more sympathetic when more resonant with American interests. Discourse on the projected realism of The Siege was able to be shifted slightly when Arab American groups organized and protested the premiere of the film, illustrating that, on the one hand, hegemonic domination of media may be contested, but on the other, that Orientalist narratives make this a challenging endeavour necessary to engage over a long period of time.

During the two-week period initiated with the January $25^{\text {th }}, 2011$, protests in Egypt, The New York Times $(n=79), A B C(n=73), C N N(n=27), \operatorname{MSNBC}(n=4)$, and Fox News $(n$ $=15$ ) produced 198 news reports archived on-line and accessed through Lexis-Nexus in March of that year. All news reports describing political events in Cairo during that time period were included in this sample. These news sources were selected not because they were expected to be similar, but in order to include a range of national news media available through the Lexis-Nexus archival service. As a print source, The New York Times devoted 
consistent attention to the subject, with the median number of words being 1018 per article. The other sources included transcripts from news broadcasts. ABC produced the highest number of programs mentioning these events among these broadcasts and did so with singular attention (median $=617$ words). Other broadcasts included this topic among several other news items, so the word counts of the transcripts are misleadingly high (CNN median = 7899 words in total broadcast; Fox news median = 1788; MSNBC median = 8167).

The plot depicting events in this discourse began with a sense of suspense, as chronicles of an "uprising" in Cairo were documented. After a few days of rather vague coverage, with the U.S. political role not being well defined until after January $28^{\text {th }}$, these sources diverged in their articulations of events as that of a people's "march" (New York Times, CNN) vs. "chaos" or "crisis" (ABC, Fox).

The victims characterized in these narratives centred on mostly the Egyptian people, as well as American tourists and journalists, but also referenced Egyptian archaeological treasures as well as the global economy, with concern for oil reserves and capitalist investors. U.S. Vice President Biden specifically requested that the Egyptian government stop imprisoning protestors and journalists, when much press was given to the harassment and beatings of American correspondents, such as Anderson Cooper. The New York Times headlined one of its articles "jitters for oil companies that ship through Egypt," raising concerns that "violence" in Egypt might "pose a threat to world energy supplies" (Krauss, 2011).

News of political protests in Egypt follows the same trajectory as that of the broader Hollywood narrative, with the villain mostly characterized by the corrupt figure of Hosni Mubarak. At first characterized as "embattled," over time he became "ruthless." Also in supporting actor role are the police, secret and officially designated, for not protecting protestors and for abusing Western journalists. Finally, U.S. news raised concerns about future villains, particularly among the Muslim Brotherhood, playing into entrenched prejudice prevalent within broader U.S. media (Karim, 2000; Said, 1991). Much of this concern is raised in connection with Israel, "anxious about the fate of the 1979 peace treaty with Egypt, should the Muslim Brotherhood emerge as the heir to the government of President Hosni Mubarak" (Kershner, 2011).

Resonant with the Hollywood narrative, the heroes of this story are the attractive, wealthy, technologically savvy youth; diverging from the conventional characterization though, as these young heroes are Egyptian and not American - for that we have the new digital media cast. Although not as central to the political agency projected through the American male hero of action-adventure, the U.S. does become the subject of many headlines of these events, as "Obama presses for change," or "Clinton calls for orderly transition to greater freedom in Egypt." Other Americans mentioned, though less frequently, as subjects of headlines regarding their perspectives and actions, include politicians and celebrities, as different as politicians Biden, Rumsfeld, Rove, and comedian Dennis Miller. However, their prominence in these headlines reinscribes the active role of the U.S. as having agency in this resistance, even if engaged through indigenous communities in a faraway territory. 
The intertwining of youth and technology as heroic partners becomes articulated in the prominent coverage of Wael Ghonim and Facebook. CNN International hosts an interview devoted to how "Facebook is really driving this revolution in many ways" (Pleitgen et al., 2011). The New York Times gives voice to agreement in a piece by El Baradei, applauding "the youth of Cairo, armed with nothing but Facebook and the power of their convictions, have drawn millions into the street to demand a true Egyptian democracy" (El Baradei, 2011).

This resonance between the projection of communication technology as a saving grace, with the missionary approach to development and the machismo American hero of actionadventure, illustrates the power of narrative when ideologically transfixed within cultural memory. Grounded in an Orientalist mentality, the Hollywood narrative prescribes technology as part of the heroic efforts that allow victims to be saved from villains. In a classic three-part structure, U.S. media relying on this narrative culminate their suspenseful telling of the story when the villain symbolically ceases to have power over these victims, in a dramatic turn of events; when there is little drama to be captured visually, artificial scenes of statues toppling can be manufactured.

\section{Limitations to the Orientalist narrative}

There are consequences to this limited narrative, not only to the narrowly structured knowledge and misguided perception of those consuming these texts without other knowledge of the region, but also to the justification of U.S. foreign policy and resource allocation. A hegemonic model of communication suggests that it is in the interests of political and economic elite within the U.S. to perpetuate Orientalist perspectives, even if to the detriment of U.S. citizens, Arab Americans, Egyptians, and global understanding.

By focusing on the young, U.S. media miss the importance of other critical groups, such as labour unions, and by focusing on the digital networking sites, media miss the importance of cell phones, transnational satellite television, and the communication landscape more broadly. Political protests in Egypt are rooted in inequity, corruption, and oppression. Demographic shifts introducing a strong, unemployed, frustrated youth matter a great deal to the mobilization of these protests.

Understanding the broader context of political resistance means taking into account global, regional, national, and transnational alliances and actions. Government control in the name of national security, whether justified as defence of "homeland" in the U.S., or coordinated with Nokia in Iran, needs to be recognized as a critical constraining factor. Regional alliances and conflicts, along with global attempts to coordinate, and perhaps at times exacerbate, are also part of this picture.

Political resistance in Egypt as of 2011 is not a Facebook revolution. We are not seeing the beauty of new media over old, or the strength of modernity over tradition, but rather how people who are frustrated use a variety of communicative approaches to organize and express their anger, to create substantive change. To privilege digital media conveniently 
overlooks critical issues of access, when only about one-third of our global population have Internet access, while another third does not even have access to toilets. To underscore "Facebook" emphasizes corporate branding over human potential. And to call this a "revolution" falls into the trap of the Hollywood narrative, when political transition is not over, and military dominance remains a crucial factor.

Political engagement within Egypt is not simply a matter of television vs. social media, given that both communication systems are vulnerable to political restrictions and corporate decisions. We need to recognize how these mediated systems allow people access to the production of content such that perspectives resistant to the dominant group can be voiced. Mediated communication can be valuable as a vehicle for mobilization, a way to leverage human and material resources, and a site for political contestation, but it is the access to the production and reception of knowledge that matters. In essence, the critical issue in political resistance is power, not technology. If our narratives of political resistance privilege the bright potential of digital media, we miss the strength of human collective engagement; let's keep our shades off, and our eyes open.

\section{References}

Alterman, J. (2011). The revolution will not be tweeted. The Washington Quarterly, 34(4): 103-116.

Deacon, D., Pickering, M., Golding, P. \& Murdock, G. (1999). Researching communications: A practical guide to methods in media and cultural analysis. London: Arnold.

Dittmer, J. (2005). Captain America's empire: reflections on identity, popular culture, and post-9/11 geopolitics. Annals of the Association of American Geographers, 95(3): 626-643.

Downing, J. (1996). Internationalizing media theory: transition, power, culture: reflections on Russia, Poland and Hungary 1980-95. London: Sage.

Eickelman, D.F. \& Anderson, J.W. (eds.) (2003). New media in the Muslim world (second edition). Bloomington: Indiana University Press.

El Baradei, M. (2011, 11 February). The next step for Egypt's opposition. The New York Times: 27.

El-Nawawy, M. \& Iskander, A. (2003). Al-Jazeera: The story of the network that is rattling governments and redefining modern journalism. Cambridge, MA: Westview Press.

Iskander, E. (2011). Connecting the national and the virtual: can Facebook activism remain relevant after Egypt's January 25 uprising? International Journal of Communication, 5: 1225-1237.

Kamalipour, Y. (ed.). 2010. Media, power and politics in the digital age: the 2009 presidential election uprising in Iran. Lanham: Rowman \& Littlefield.

Karim, K. H. (2000). Islamic peril: media and global violence. Montreal: Black Rose Books.

Kershner, I. (2011, 3 February). Egypt's upheaval hardens Israel's stance on peace. The New York Times: 13.

Khalil, J. (2011). Understanding the threat to Arab youth uprisings. Ibraaz: Kamal Lazaar Foundation.

Kraidy, M. (2010). Reality television and Arab politics: contention in public life. New York: Cambridge University Press.

Krauss, C. (2011, 3 February). Jitters for oil companies that ship through Egypt. The New York Times: 1.

Krippendorff, K. (2008). Cybernetics' reflexive turn. Cybernetics and Human Knowing, 15(3-4): 173-184. 
Lynch, M. (2006). Voices of the new Arab public: Iraq, Al-Jazeera, and Middle East politics today. New York: Columbia University Press.

Marchetti, G. (1989). Action-Adventure as ideology. In Angus, I. \& Jhally, S. (eds.) Cultural politics in contemporary America (pp. 182-197). New York: Routledge.

McKee, R. (1997). Story: substance, structure, style, and the principles of screenwriting. New York: Regan Books.

Miller, T. (2007). Global Hollywood 2010. International Journal of Communication, 1: 1-4.

Neale, S. (2004). Action-Adventure as Hollywood genre. In Y. Tasker (ed.), Action and Adventure Cinema (pp.71-83). New York: Routledge.

Noakes, J. \& Wilkins, K. (2002). Shifting frames of the Palestinian movement. Media, Culture, and Society, 24(5): 649-671.

Park, J. \& Wilkins, K. (2005). “Re-orienting the orientalist gaze.” Global Media Journal, 4(6), Article 2.

Pleitgen, F., Watson, I., Damon, A., Lu Stout, K., Wedeman, B., Maktabi, R., Bolduan, K., Stevens, A. (2011, 11 February). Uprising in Egypt; gauging the impact in the Middle East; the call from Washington. CNN, 8:00 EST.

Rameriz-Berg, C. (2011). Personal communication.

Said, E. (1978). Orientalism. New York, NY: Pantheon Books.

Said, E. (1997). Covering Islam: how the media and the experts determine how we see the rest of the world. New York: Vintage Books.

Sakr, N. (2007). Arab television today. London: I.B. Tauris.

Shaheen, J.G. (2001). Reel bad Arabs: how Hollywood vilifies a people. New York: Olive Branch Press.

Sieb, P. (2008). The Al Jazeera effect: how the new global media are reshaping world politics. Dulles: Potomac Books.

Valenti, J. (2002). Hollywood and the war against terror. New Perspectives Quarterly (NPQ), 19(2): 69-72.

Wilkins, K. (1995). Middle Eastern women in Western eyes: a study of US press photographs of Middle Eastern women. In Y. Kamalipour (ed.) The US Media and the Middle East: Image and Perception (pp. 50-61). Westport, CT: Greenwood Press.

Wilkins, K. (2004). Communication and transition in the Middle East: a critical analysis of US intervention and academic literature. Gazette: The International Journal for Communication Studies, 66(6): 483-496. Wilkins, K. (2008). Home/Land/Security: what we learn about Arab communities from Action-Adventure film. Lanham, MD: Lexington Books.

Wilkins, K. \& Downing, J. (2002). Mediating terrorism: text and protest in the interpretation of The Siege. Critical Studies in Media Communication. 19(4): 419-437.

Wilson, C. \& Dunn, A. (2011). Digital media in the Egyptian revolution: descriptive analysis from the Tahrir data sets. International Journal of Communication, 5: 1-20.

Wright, R. (2011). Rock the casbah: rage and rebellion across the Islamic world. New York: Simon and Schuster.

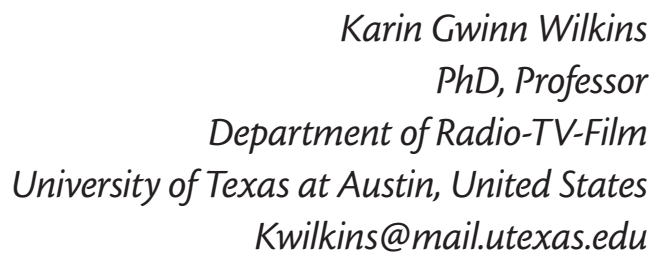

